\title{
Somatic Embryogenesis from Immature Cotyledons of Soybean (Glycine max (L.) Merr.): Ontogeny of Somatic Embryos
}

\author{
Karla Galvão Bezerra dos Santos ${ }^{1}$, Jorge Ernesto de Araújo Mariath ${ }^{2}$, Maria Cecília C. \\ Moço $^{2}$ and Maria Helena Bodanese-Zanettini ${ }^{1 *}$ \\ ${ }^{1}$ Departamento de Genética; Universidade Federal do Rio Grande do Sul; C. P. 15053; 91501-970; Porto Alegre - \\ RS - Brasil. ${ }^{2}$ Departamento de Botânica; Universidade Federal do Rio Grande do Sul; Porto Alegre - RS - Brasil
}

\begin{abstract}
Soybean somatic embryos obtained from immature zygotic embryos were histologically analyzed in order to determine possible ontogenetic routes followed by these embryos. The proembryo stage and globular, heart-shaped, torpedo and cotyledonary embryo stages were found, closely resembling the ontogeny of zygotic embryos. However, the absence of a characteristic suspensor as well as the delay in the establishment of inner organization were the main differences between these two embryogenic processes.
\end{abstract}

Key words: Glycine max, ontogeny, somatic embryo

\section{INTRODUCTION}

Somatic embryogenesis can be described as the process through which haploid or diploid somatic cells develop into different plants through characteristic embryological stages without fusion of gametes (Williams and Maheswaran, 1986). This phenomenon has been observed in tissue cultures of several angiosperm and gymnosperm plant species. The anatomical aspect of somatic embryos has been presented by many authors (Auboiron et al., 1990; Gill and Saxena, 1992; Decout et al., 1994; Suhasini et al., 1994). However, only some studies characterized the different ontogenetic stages of these embryos (Fransz and Schel, 1991; Toonen et al., 1994; Yeung et al., 1996). In soybean, histological sections of de novo formed embryogenic structures can be found in some reports (Barwale et al., 1986;
Finer and McMullen, 1991; Kiss et al., 1991; Liu et al., 1992; Sato et al., 1993). However, a characterization of the different developmental stages of soybean somatic embryos was performed only by Christou and Yang (1989), Fernando et al. (2002), and Rodrigues et al. (2005). In this study, we analyzed different soybean somatic embryos in order to characterize ontogenetic routes followed by these embryos by means of histological approaches. We also present three differentiation routes followed by the somatic embryos based on the comparison between somatic and zygotic embryogenesis.

\section{MATERIALS AND METHODS}

\footnotetext{
* Author for correspondence
} 
Somatic embryos were obtained from immature cotyledons of soybean (Glycine max (L.) Merr. cv BRAGG, IAS-5 and RS-7) as previously described by Santos et al. (1997). Explants were cultured on a solid induction medium (MSD40, Finer, 1988) containing MS salts (Murashige and Skoog 1962), Gamborg's B5 vitamins (Gamborg et al., 1968), $40 \mathrm{mg} / \mathrm{l}$ 2,4-D, 6\% sucrose, and $0.7 \%$ agar $(\mathrm{pH}$ 5.7) in the presence or absence of $\mathrm{AgNO}_{3}$ (1.8 or $4.2 \mathrm{mg} / \mathrm{l})$ or aminoethoxyvinylglycine-AVG $(0.8$ or $2.0 \mathrm{mg} / \mathrm{l})$. After three months on induction medium, somatic embryos were transferred, individually or in clusters, to maturation medium. This medium consisted of MS salts, Gamborg's B5 vitamins, $6 \%$ maltose, $0.3 \%$ phytagel and 0.5 $\%$ activated charcoal. Since the morphological aspects of embryos obtained from different media were very similar, the collection and fixation were randomly made.

Somatic embryos at different developmental stages were fixed in formaldehyde:acetic acid:alcohol (FAA - 5:5:90 v/v, Johansen, 1940) for $48 \mathrm{hrs}$ and stored in $70 \%$ ethanol. These tissues were dehydrated in an ethanol series (Johansen, 1940)

and taken into hydroxyethylmetacrylate (Jung's Historesin) (Gerrits and Smid, 1983). Serial $5 \mu \mathrm{m}$ sections were cut on a Base Sledge Microtome (Leitz 1400), mounted on cytological glass slides and stained with $0.05 \%$ toluidine blue (3-5 min.). The investigations and photomicrographs and/or macrographs were conducted in a Leitz microscope (Dialux-20EB) and in a stereoscopic microscope (Wild-M7A). In both cases, a Leica camera MD-2 was used.

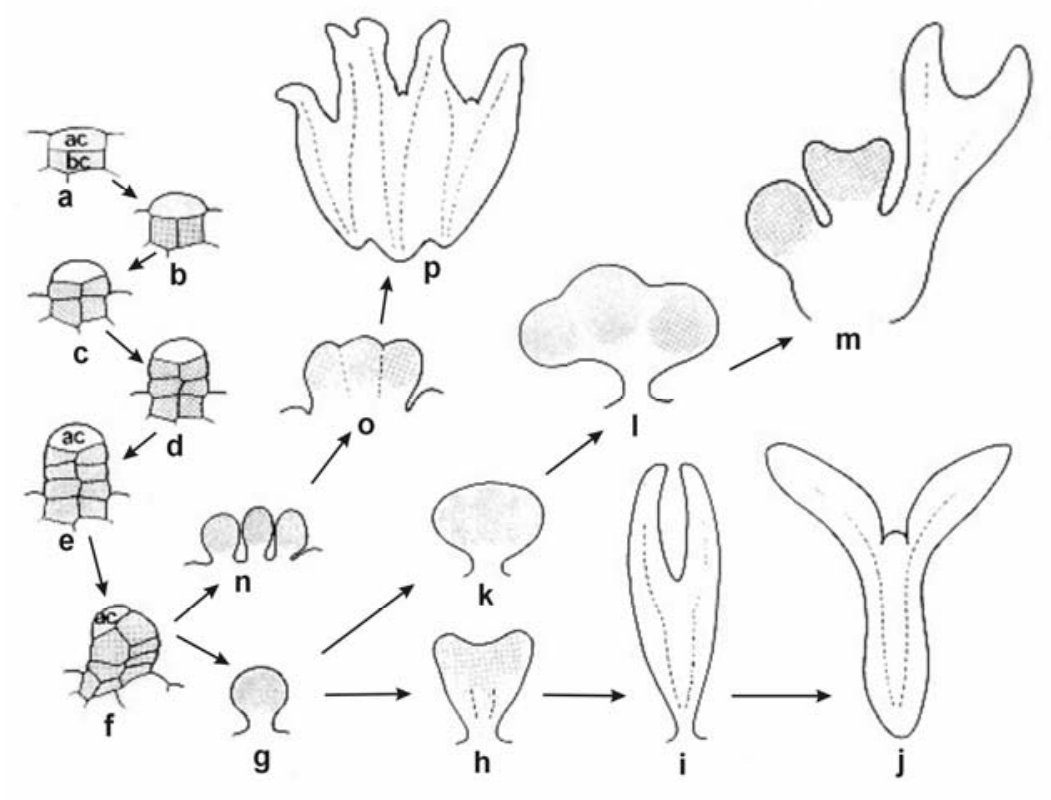

Figure 1 - Schemata of soybean (Glycine max) somatic embryo ontogenetic routes. a. First division of somatic embryo; b. Anticlinal division of the proembryo basal cell; c-f. Periclinal divisions in the two series of derivatives from the basal cell; g. Globular embryo; h. Heart embryo; i. Torpedo embryo; j.Cotyledonary embryo; k. Enlarged primary globular embryo; 1. Enlarged structure with three growth centers; m. Differentiation of secondary embryos from an enlarged primary embryo; n. Early-stage globular embryos originated from adjacent epidermal cells; o. Fusion of globular embryos; p. Fasciated cotyledonary embryos. $a c=$ apical cell; $b c=$ basal cell.

\section{RESULTS AND DISCUSSION}

Somatic embryos were first observed on the surface of cotyledon explants four weeks after initiation of cultures. With increased time in culture, secondary globular embryos were formed on the surface of the older embryos. When transferred to maturation medium, these embryos developed from globular to heart-shaped, torpedo and cotyledonary stages. 
Histological analysis of soybean somatic embryos revealed three possible ontogenetic routes (Fig 1.) The first route showed an ontogenetic similarity with soybean zygotic embryo development stages (Carlson, 1973; Chamberlin et al., 1994). In this route, the primary somatic proembryo initiated from a periclinal division of one epidermal cell of the explant. This division originated an inner basal cell and an outer apical one of the proembryo (Fig. 2 and 1a). Liu et al. (1992) and Gyulai et al.(1993) also showed somatic embryos with a single-cell origin. In contrast, Fernando et al. (2002) reported that none of the somatic embryos presented unicellular origin in two studied soybean genotypes. According to the authors, the globular structures were originated from subepidermal cell divisions in the cotyledonary mesophyll. Nevertheless, in a detailed histological study in soybean anther culture, somatic embryogenesis of unicellular origin was observed from the epidermis and the middle layer, and of multicelluar origin from connective calluses (Rodrigues et al., 2005). The basal cell divided anticlinally, forming two derived cells which through periclinal divisions, formed two series of suspensor-resembling cells, where the apical cell was maintained as initial (Figs. 3 and 1b-f). Later, the apical cell divided forming a globular embryo (Fig. 4). At subsequent proembryo stage was not observed a well-defined suspensor structure, although, in a few cases, some layers of more densely-stained cells seemed to support a connection between the globular embryo and the explant (Fig.5 and 1g). These cells could represent either a disorganized suspensor or a differential developmental pattern of this structure. The absence of a suspensor-like structure was described by Fernando et al. (2002). These different results could be explained due the origin of the embryos. According to Williams and Maheswaran (1986), the multicellular origin normaly produces somatic embryos fused with parental tissue, while an unicellular origin gave rise to embryos attached by a suspensor-like organ.

The protoderm was only identified in late globular staged embryos but no evidence of inner cell organization was observed neither in globular nor in early heart stage embryos (Figs. 5 and 6). The procambial initials arose in late heart-shaped embryos (Fig. 7, arrows and 1h).
The absence of a well-defined suspensor as well as the delay in the formation of inner organization represent remarkable differences between the soybean somatic and zygotic embryogenesis. In zigotic embryos of this species, the suspensor was present even in developed cotyledonary embryos (Carlson, 1973) whereas differentiated internal tissues (such as procambium, shoot and root apical meristems) could be found in heart-shaped embryos (Chamberlin et al., 1994).

During the late torpedo and cotyledonary stage embryos, all meristematic tissues were developed: protoderm, procambium, ground meristem, shoot and root apical meristems (Figs. 8-11, 1i-j). The somatic embryos obtained in this study showed normal developed cotyledons, different from those presented by Christou and Yang (1989) in the same species. These authors, who carried out a detailed histological and biochemical study, concluded that with the possible exception of the cotyledonary stage, soybean somatic embryo development resembled very closely the development of zygotic embryos. The main difference between the study carried out by Christou and Yang (1989), and our analysis was the culture medium. In the present study, after induction, the embryos were developed in absence of 2,4-D, while the induced ones by Christou and Yang (1989) were kept in presence of a synthetic auxin. Thus, the removal of the somatic embryos from the auxin-containing medium must be crucial to the normal cotyledons development.

Numerous abnormal histodifferentiated embryos have been observed as decribed by Santos et al. (1997). In the present study, a torpedo-like embryo resembling a trumpet was histologically analysed. In this embryo type, the procambium is welldefined but neither an apical shoot meristem nor a root meristem were detected (Fig.12). Fernando et al. (2002) also recorded soybean trumpet embryos but they observed a normal root meristem while the shoot meristem was absent. The analysis of histological sections in mature trumpet embryos in peanuts showed a poorly developed meristematic region (Wetzstein and Baker, 1993). Embryos like these presented a low conversion rate not only in peanuts (Wetzstein and Baker, 1993) but also in soybean (Buchheim et al., 1989, Kiss et al., 1991; Fernando et al., 2002). 

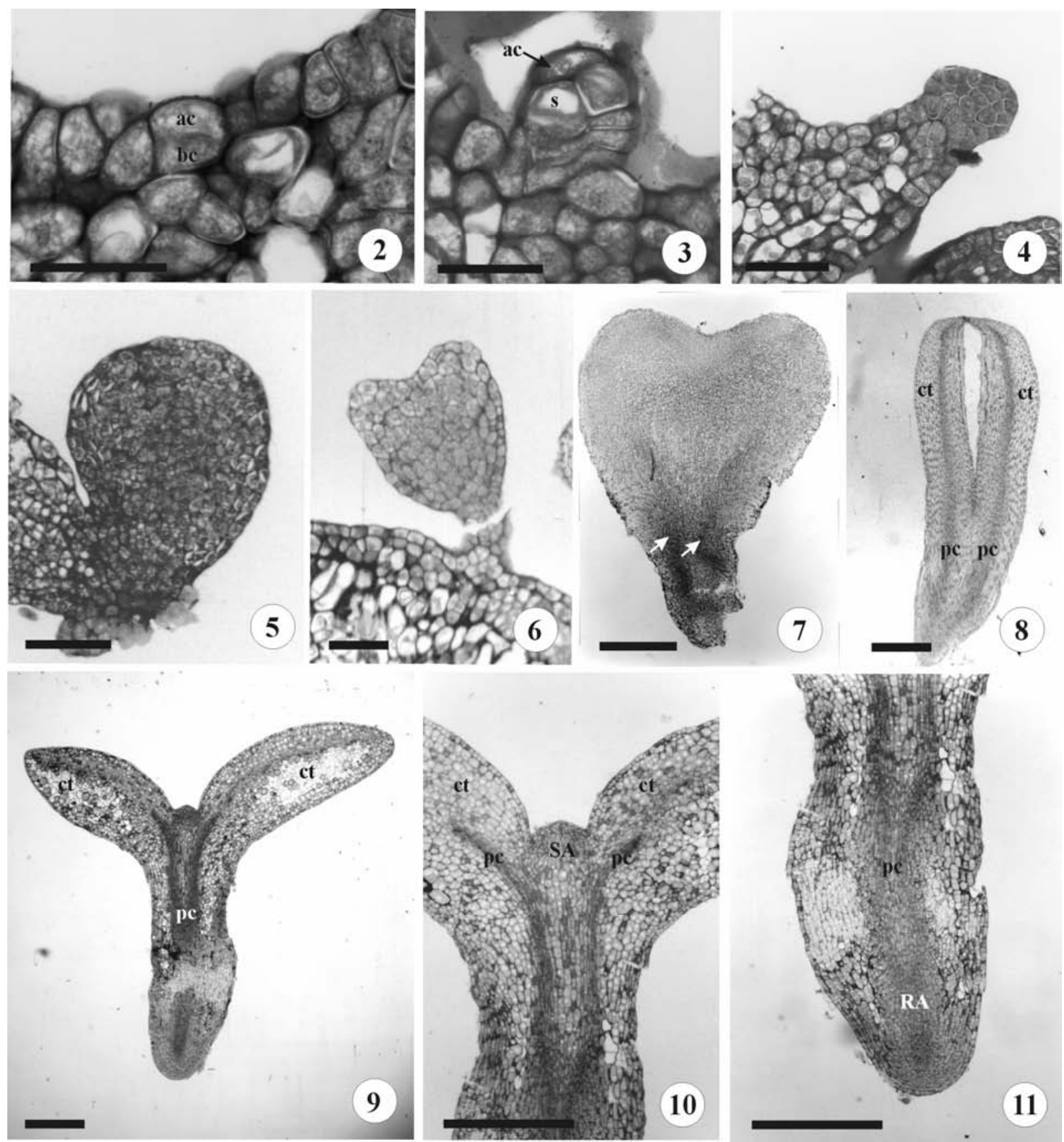

11

Figures 2-11 - Ontogeny of soybean (Glycine max) primary somatic embryos in longitudinal sections. 2. apical cell and basal cell from periclinal division of explant epidermis. 3 . Establishment of suspensor through basal cell divisions. 4. Early globular stage embryo. 5. Late globular stage embryo. 6. Early heart stage embryo. 7. Later heart stage embryo with procambial initials (arrows). 8. Late torpedo stage embryo. 9. Cotyledonary stage embryo. 10. Detail of shoot apex of the embryo in Fig. 9. 11. Detail of the root apex of the embryo in Fig. 9. ac= apical cell; $b c=$ basal cell; $c t=$ cotyledons; $\mathrm{pc}=$ procambium; $\mathrm{RA}=$ root apex; $\mathrm{s}=$ suspensor; $\mathrm{SA}=$ shoot apex. Scale bar $=50 \mu \mathrm{m}$ in 2,3 and 7;100 $\mu \mathrm{m}$ in 4,5 and $6 ; 0,5 \mathrm{~mm}$ in 8 to 11 . 


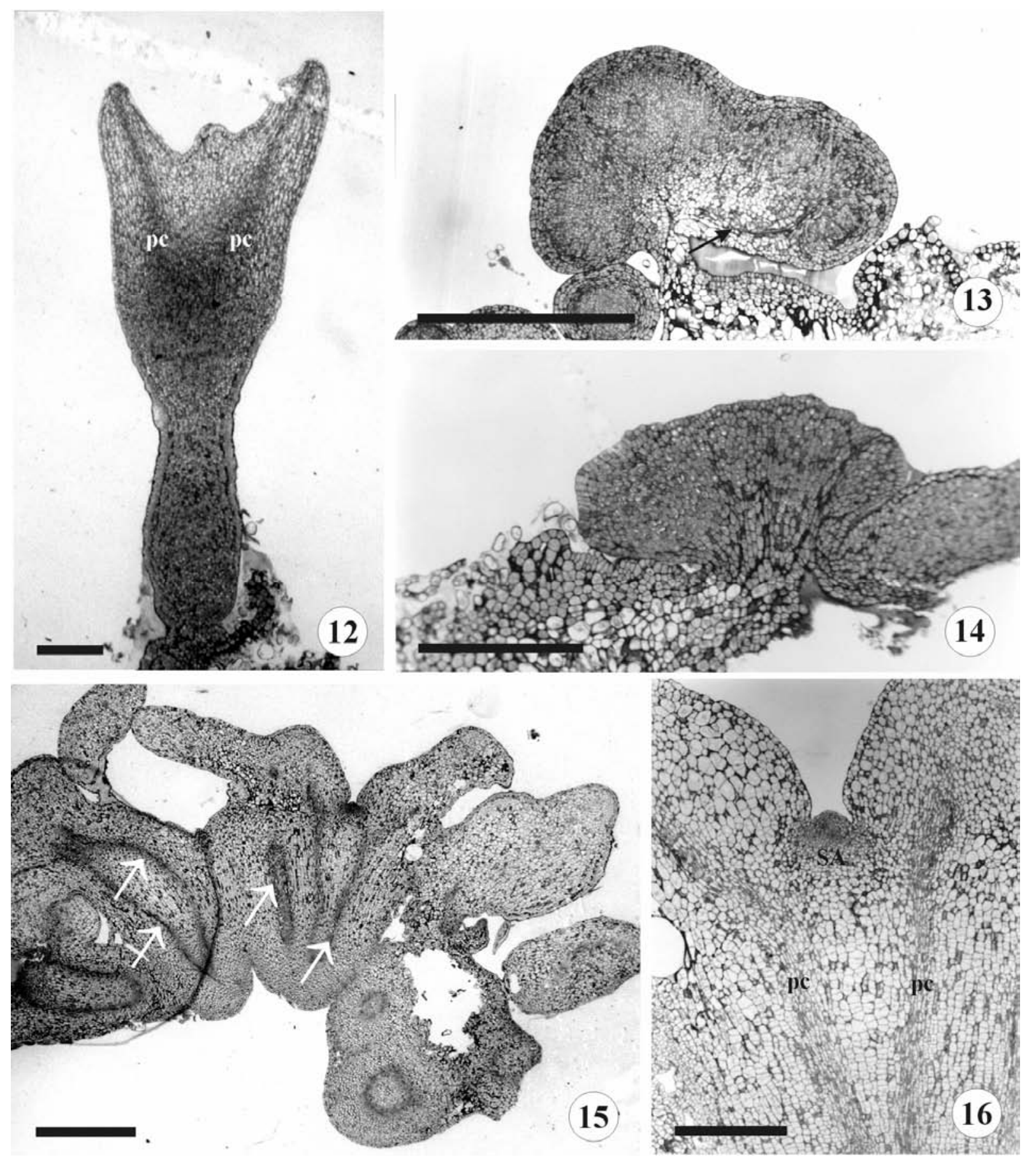

Figures 12-16 - Ontogeny variation of soybean (Glycine max) somatic embryos in longitudinal sections. 12. Trumpet embryo grew on an induction medium with a high concentration of 2,4-D.13. Enlarged embryos with growth centers, procambial initials (arrow). 14. Enlarged structure from fused early-staged globular embryos. 15. Fasciated cotyledonary embryos with individualized procambium (arrows). 16. Shoot apex detail from Fig. 15 . pc= procambium; $\mathrm{ct}=$ cotyledons; $\mathrm{SA}=$ shoot apex. Scale bar $=5 \mathrm{~mm}$ in 12,13 and $14 ; 10 \mathrm{~mm}$ in 15 and 16 . 
In the second route, the primary globular embryos showed enhanced growth (Fig. 1k). The histological analysis of these enlarged structures pointed out the existence of meristematic centers within the protoderm (Figs. 11 and 13). In some cases, procambial initials were found (Fig.13, arrow). These growth centers might originate subepidermal secondary embryos (Fig. 1m). Finer (1988), analyzing histological sections of soybean somatic embryos, found secondary embryos with subdermal origin. Nevertheless, the possibility of such embryos to have epidermal origin was considered by the author.

In the third route, an enlarged structure could be formed by the fusion of early-staged globular embryos (Figs. 1n-p and 14,). After maturation, the

fused embryos developed into fasciated cotiledonary embryos (Fig. 1p).Histological sections showed an epidermal layer shared by most of the fused embryos (Fig. 14). On the other hand, their vascular systems were individualized (Fig. 15, arrows) and the shoot apex was wellestablished (Fig. 16). Closely-resembling routes of development were also found in carrots, but histological analyses were not been carried out (Ammirato, 1987).

\section{ACKNOWLEDGMENTS}

We are grateful to S. Richter and B. Cassol for technical assistance and R. P. dos Santos for his help in preparing the drawings. This research was supported by FAPERGS, FINEP, and CAPES.

\section{RESUMO}

Embriões somáticos de soja em diferentes estádios de desenvolvimento, obtidos a partir de embriões zigóticos imaturos, foram estudados histologicamente com o objetivo de caracterizar as possíveis rotas ontogenéticas seguidas por esses embriões. Foram encontrados embriões nos estádios de proembrião, globular, cordiforme, torpedo e cotiledonar, revelando uma ontogenia similar àquela encontrada nos embriões zigóticos. Entretanto, a ausência de um suspensor definido, bem como o retardo no aparecimento de organização interna são diferenças marcantes entre esses dois processos embriogênicos. Além dessa rota de desenvolvimento, prováveis rotas alternativas de diferenciação são apresentadas.

\section{REFERENCES}

Ammirato, P. V. (1987), Organizational events during somatic embryogenesis. In: Green, C. E.; Somers, D. A.; Hackett, W. P.; Biesboer, D. D. and Liss, A. R. (Eds.). Plant tissue and cell culture. Inc New York. pp. 57-81.

Auboiron, E.; Carron, M. P. and Michaux-Ferrière, N. (1990), Influence of atmospheric gases, particularly ethylene, on somatic embryogenesis of Hevea brasiliensis. Plant Cell Tissue and Organ Culture, 21, 31-37.

Barwale, U. B.; Kerns, H. R. and Widholm, J. M. (1986), Plant regeneration from callus cultures of several soybean genotypes via embryogenesis and organogenesis. Planta, 167, 473-481.

Buchheim, J. A.; Colburn, S. M. and Ranch, J. P. (1989), Maturation of soybean somatic embryo and the transition to plantlet growth. Plant Physiology, 89, 768-775.

Carlson, J. B. (1973), Morphology. In: Caldwell, B. E. (Ed.). Soybeans: improvement, production, and uses. Madison, Wisconsin, USA: American Society of Agronomy, Inc, Publisher. pp. 17-95.

Chamberlin, M. A.; Horner, H. T. and Palmer, R. G. (1994), Early endosperm, embryo, and ovule development in Glycine max (L.) Merr. International Journal of Plant Sciences, 155, 421-436.

Christou, P. and Yang, N. S. (1989), Developmental aspects of soybean (Glycine max) somatic embryogenesis. Annals of Botany, 64, 225-234.

Decout, E.; Dubois, T.; Guedira, M.; Dubois, J.; Audran, J. C. and Vasseur, J. (1994), Role of temperature as a triggering signal for organogenesis or somatic embryogenesis in wounded leaves of chicory cultured in vitro. Journal of Experimental Botany, 45, 1859-1865.

Fernando, J. A.;Vieira, M. L. C.; Geraldi, I. O. and Appezzato-da-Gloria, B. (2002), Anatomical study of somatic embryogenesis in Glicine max (L.) Merrill. Brazilian Archives of Biology and Technology, 45, 277-286.

Finer, J. J. (1988), Apical proliferation of embryogenic tissue of soybean (Glycine max (L.) Merrill). Plant Cell Reports. 7, 238-241.

Finer, J. J. and Mcmullen, M. D. (1991), Transformation of soybean via particle bombardment of embryogenic suspension culture tissue. In vitro Cellular and Developmental Biology., 27, 175-182. 
Fransz, P. F. and Schel, J. H. N. (1991), An ultrastructural study on the development of Zea mays somatic embryos. Canadian Journal of Botany, 69, 858-865.

Gamborg, O. L.; Miller, R. A. and Ojima, K. (1968), Nutrient requirements of suspension cultures of soybean root cells. Experimental Cell Research., 50, 151-158.

Gerrits, P. O. and Smid, L. (1983), A new, less toxic polymerization system for the embedding of soft tissues in glycol methacrylate and subsequent preparing of serial sections. Journal of Microscopy, 132, 81-85

Gill, R. and Saxena, P. K. (1992), Direct somatic embryogenesis and regeneration of plants from seedling explants of peanut (Arachys hypogaea): promotive role of thidiazuron. Canadian. Journal of Botany, 70, 1186-1192.

Gyulai, G.; Kiss, E.; Csillag, A. and Heszky, L. E. (1993), Developmental analysis of primary and secondary somatic embryogenesis in soybean tissue culture. Acta Biol. Hung., 44, 189-196.

Johansen, D. A. (1940), Plant microtechnique. New York; London: McGraw-Hill Publ.

Kiss, E.; Heszky, L. E.; Gyulai, G.; Horváth, H. S. and Csillag, A. (1991), Neomorph and leaf differentiation as alternative morphogenetic pathways in soybean tissue culture. Acta Biol. Hung., 42, 313-321.

Liu, W.; Moore, P. J. and Collins, G.B. (1992), Somatic embryogenesis in soybean via somatic embryo cycling. In vitro Cellular and Developmental Biology, 28, 153-160.

Murashige, T. and Skoog, F. (1962), A revised medium for rapid growth and bioassays with tobacco tissue cultures. Physiologia. Plantarum, 15, 473-497.

Rodrigues, L. R.; Oliveira, J. M. S.; Mariath, J. E. A. and Bodanese-Zanettini, M. H. (2005), Histology of embryogenic responses in soybean anther culture. Plant Cell, Tissue and Organ Culture, 80, 129-137.

Santos, K. G. B.; Mundstock, E. and BodaneseZanettini, M. H. (1997), Genotype-specific normalization of soybean somatic embryogenesis through the use of an ethylene inhibitor. Plant Cell Reports, 16, 859-864.
Sato, S.; Newell, C.; Kolacz, K.; Tredo, L.; Finer, J. and Hinchee, M. (1993), Stable transformation via particle bombardment in two different soybean regeneration systems. Plant Cell Reports, 12, 408413.

Suhasini, K.; Sagare, A. P. and Krishnamurthy, K. V. (1994), Direct somatic embryogenesis from mature embryo axes in chickpea (Cicer arietinum). Plant Science, 102, 189-194.

Toonen, M. A. J.; Hendriks, T.; Schmidt, Ed D. L.; Verhoeven, H. A.; Kammen, Ab Van and Vries, S. C. (1994), Description of somatic-embryo-forming single cells in carrot suspension cultures employing video cell tracking. Planta, 194, 565-572.

Wetzstein, H. Y. and Baker, C. M. (1993), The relationship between somatic embryo morphology and conversion in peanut (Arachys hypogaea L.). Plant Science, 92, 81-89.

Williams, E. G. and Maheswaran, G. (1986), Somatic embryogenesis: factors influencing coordinated behavior of cells as an embryogenic group. Ann. Bot., 57, 443-462.

Yeung, E.C.; Rahman, M.H. and Thorpe, T.A. 1996. Comparative development of zygotic and microsporederived embryos in Brassica napus L. Cv Topas. I. Histodifferentiation. International Journal of Plant Science, 157, 27-39.
Received: July 02, 2004; Revised: December 23, 2004; Accepted: May 19, 2005. 